\title{
Photosynthetic productivity of summer barley in conditions of Forest-steppe Right-bank
}

\section{Romaniuk V.}

Institute of forages and agriculture of Podillia of NAAS, Yunosti avenue, 16, Vinnytsia, 21100, Ukraine; e-mail: r_viktori@ukr.net

The purpose. To determine influence of complex application of doses of nitric fertilizers and growth regulating substances on display of character of formation of photosynthetic and grain efficiency of different varieties of summer barley in conditions of Forest-steppe Right-bank. Methods. Applied general scientific methods (dialectics, experiment, analysis and synthesis, method of hypotheses), and special: field - for studying interaction of subject of researches with weather conditions and receptions of technology of cultivation; visual; measuring and weight; quantitative; physiological; laboratory — for establishment of qualitative characteristics of soil of test plot; dispersive, correlation and regression - for determination of reliability of distinctions between factors, pair and plural dependences. Results. Influence of complex application of doses of nitric fertilizers and regulators of growth of plants on formation of photosynthetic and seed efficiency of summer barley of varieties Nabat and Vinnitskiy 28 is investigated. It is noted that in variants of experiment with maximal parameters of photosynthetic efficiency, in particular accumulation of organic substance $\left(1045,9-1035,1 \mathrm{~g} / \mathrm{m}^{2}\right)$, pure efficiency of photosynthesis $\left(5,5-5,9 \mathrm{~g} / \mathrm{m}^{2}\right)$, content of chlorophylls «a+b» $(2,29-2,14 \mathrm{mg} / \mathrm{g}$ of crude weight), it is observed the maximal productivity of grain of culture. The highest productivity of grain for varieties Nabat $(6,39$ $\begin{array}{lllll}t / h e c t a r e) & \text { and } & 28 & (5,78 & t / h e c t a r e)\end{array}$ was gained in variants of experiment where on phosphoric-potash background $\mathrm{P}_{45} \mathrm{~K}_{45}$ they entered nitric fertilizers in doze of $\mathrm{N}_{90}$ and morpho-regulator Terpal in a phase of the beginning of tubing. That was more accordingly on $2,21 \mathrm{t} /$ hectare, or $52,8 \%$ and $1,97 \mathrm{t} /$ hectare, or $51,7 \%$ in comparison with the control (on plots without fertilizers and growth regulators). Conclusions. Optimization of technology of cultivation of summer barley due to the balanced system of fertilizer, namely entering of nitric fertilizers in doze of $\mathrm{N}_{90} \mathrm{P}_{45} \mathrm{~K}_{45}$ and application of growth regulators (Binom or Terpal), provides realization of genetic potential of varieties Nabat and Vinnitskiy 28 on $60-70 \%$ and level of productivity of grain $-6,39$ and $5,78 \mathrm{t} /$ hectare accordingly.

Key words: summer barley, variety, doze of nitric fertilizer, growth regulator, photosynthetic productivity, productivity.

DOI: https://doi.org/10.31073/agrovisnyk201903-12

Introduction. Barley is one of the leading grain-forage crops in Ukraine and it ranks second by the cropping areas and production after winter wheat. In recent years, the area under barley has occupied over 1.6 million hectares. In the structure of cropping areas of the Forest-Steppe, spring barley occupies nearly $6 \%$, and in some years it has occupied $8-10 \%$ as an insurance crop for winter crops [1, 2].

In addition to a complex of abiotic factors, instability of barley grain production is also greatly influenced by noncompliance with the growing technology, which in its turn negatively affects the growth and development of the root system, formation of the plant photosynthetic apparatus, as well as the duration and effectiveness of its functioning, and it also greatly reduces crop productivity and product quality [3, 4].

The studies show that the processes of absorption, movement, distribution of metabolites and assimilation of mineral nutrients are the basis for the yield formation of the crop, in particular spring barley. Retardants can have a significant effect on the redistribution of assimilates between plant organs, changing the hormonal balance. The main features of their effect are the blocking of gibberellin synthesis or formation of the hormone-receptor complex, which reduces the intensity of linear growth of the stem, its thickening, intensification of the growth of the root system, restructuring of the nature of donor-acceptor relations of plants. It is known that changes in the growth and development of plants under the effect of retardants are related to 
their influence on the certain stages of the metabolism of plant cells, which causes changes in the activity of the photosynthetic apparatus, nucleic-protein and carbohydrate metabolism, as well as other processes in the yield formation [5].

Thus, modern technologies of spring barley cultivation should provide optimal conditions for the formation of a powerful photosynthetic apparatus of plants and ensure the duration of its productive operation in time.

The purpose of the research was to determine the effect of the complex application of doses of nitrogen fertilizers and treatment with growth regulators on the formation of photosynthetic and grain productivity of different spring barley varieties under the conditions of the right-bank Forest-Steppe.

Research methodology. The research was conducted during 2009-2011 at the Institute of Feeds and Agriculture of Podillia of NAAS on the gray forest mid-loamy soils with humus content of $2.20 \%$. It was supposed to study the effect and interaction of three factors: A - variety (Nabat, Vinnytskyi 28); B - rates of nitrogen fertilizers ( $\mathrm{N}_{45}, \mathrm{~N}_{60}, \mathrm{~N}_{90}$ ); C - plant growth regulators (Terpal, Binom). Fertilization was carried out in spring before tillage. Retardant was applied in the phase of tube formation.

The research was conducted according to "Methodology of Field Experiment" [6]. Indices of photosynthetic productivity were determined by the method of A.A. Nychyporovych [7, 8].

Research results. The process of photosynthesis, which results in organic matter formation, is attracting more and more attention of numerous researchers. Analysis of scientific literary sources of domestic and foreign scientists shows that the growth of crop productivity is caused primarily by the increased activity and efficiency of the plant assimilation apparatus [11]. In recent years, the relationship of grain productivity and the structural organization, effectiveness and mechanisms of protection of photosynthetic apparatus at the level of both the initial processes of photosynthesis [9] and coenotic relationships [10] have been intensively studied.

It should be noted that the fertilization system is an important element of the cultivation technology that affects the formation and duration of the active functioning of the leaf surface area. Under their effect, metabolic processes in plants are enhanced, the process of photosynthesis is intensified, therefore, when applying nitrogen fertilizers, plants have an enlarged area of assimilation surface, which affects the assimilation of nutrients and increases crop productivity [12].

It was established that application of nitrogen fertilizers at the rate of $\mathrm{N}_{45-90}$ on the phosphorus-andpotassium $\mathrm{P}_{45} \mathrm{~K}_{45}$ background contributed to the increase of the barley assimilation surface in different varieties compared with the control variant. Hence, in the tillering phase (where the maximum formation of assimilation surface was observed), the application of nitrogen fertilizers at the rate of $\mathrm{N}_{45}$ increased the leaf area in Nabat variety by 3.8 thousand $\mathrm{m}^{2} / \mathrm{ha}$, at the rate of $\mathrm{N}_{60}-6.0$ thousand $\mathrm{m}^{2} / \mathrm{ha}$ and at the rate $\mathrm{N}_{90}-7.6$ thousand $\mathrm{m}^{2} / \mathrm{ha}$, while in Vinnytskyi 28 variety, respectively, by $3.9,5.8$ and 7.0 thousand $\mathrm{m}^{2} /$ ha, respectively, with absolute values in the control of 47.7 and 46.9 thousand $\mathrm{m}^{2} /$ ha, respectively (Table 1 ).

Since the retardants block the synthesis or reception of gibberellins and, as a consequence, inhibit the excessive growth of vegetative organs, the inhibitory effect of retardants on the photosynthetic productivity is fulfilled through the changes at the level of organization of the photosynthetic apparatus, i.e. formation of the total leaf surface area of plants [13].

Our research has confirmed the revealed dependence on the effect of the growth regulators on the formation of the leaf surface area. It has been established that the treatment of spring barley crops with the growth regulators Binom or Terpal inhibited formation of the assimilation surface in spring barley plants. Thus, on the average in the experiment, treatment with Binom reduced leaf area in Nabat variety by 0.3-0.9 thousand $\mathrm{m}^{2} /$ ha, and in Vinnytskyi 28 variety by 0.3-0.6 thousand $\mathrm{m}^{2} /$ ha compared to the variants without application of the growth regulator. When applying Terpal, leaf area decreased by 1.0-2.1 thousand $\mathrm{m}^{2} / \mathrm{ha}$ and 1.0-1.7 thousand $\mathrm{m}^{2} / \mathrm{ha}$, although these indices are not substantial at $5 \%$ level of significance. 
1. Maximum indices of photosynthetic productivity of spring barley of Nabat variety depending on the rates of nitrogen fertilizers and plant growth regulators (on average for 2009-2011), * $M \pm m$

\begin{tabular}{|c|c|c|c|c|c|c|}
\hline \multirow[t]{2}{*}{$\begin{array}{l}\text { Plant } \\
\text { growth } \\
\text { regulator }\end{array}$} & \multirow[t]{2}{*}{ Fertilizers } & $\begin{array}{c}\text { Leaf } \\
\text { surface } \\
\text { area, } \\
\text { thousand } \\
\mathrm{m}^{2} / \mathrm{ha} \\
\end{array}$ & $\begin{array}{l}\text { Photosynthetic } \\
\text { potential, mln } \\
\mathrm{m}^{2} \text {.days/ha }\end{array}$ & $\begin{array}{c}\text { Net } \\
\text { photosynthetic } \\
\text { productivity, } \mathrm{g} / \mathrm{m}^{2} \\
\text { per day }\end{array}$ & $\begin{array}{c}\text { Dry matter } \\
\text { accumulation, } \\
\mathrm{g} / \mathrm{m}^{2}\end{array}$ & $\begin{array}{l}\text { Chlorophyll } \\
\text { content } \\
\text { "a+b", } \\
\text { mg/g of } \\
\text { crude mass }\end{array}$ \\
\hline & & earing & milk-wax maturity & $\begin{array}{c}\text { tillering-tube } \\
\text { formation }\end{array}$ & $\begin{array}{l}\text { milk-wax } \\
\text { maturity }\end{array}$ & $\begin{array}{c}\text { tube } \\
\text { formation }\end{array}$ \\
\hline \multirow{5}{*}{$\begin{array}{l}\text { Without } \\
\text { PGR }\end{array}$} & $\begin{array}{c}\text { Without } \\
\text { fertilizers }\end{array}$ & $47.7 \pm 0.6$ & 1.946 & 4.1 & $603.1 \pm 1.8$ & 1.59 \\
\hline & $\mathrm{P}_{45} \mathrm{~K}_{45}$ & $47.9 \pm 0.6$ & 1.969 & 4.2 & $604.3 \pm 2.2$ & 1.71 \\
\hline & $\mathrm{N}_{45} \mathrm{P}_{45} \mathrm{~K}_{45}$ & $51.5 \pm 0.5$ & 2.304 & 4.9 & $907.6 \pm 2.5$ & 1.73 \\
\hline & $\mathrm{N}_{60} \mathrm{P}_{45} \mathrm{~K}_{45}$ & $53.7 \pm 0.9$ & 2.482 & 5.1 & $981.9 \pm 2.7$ & 1.77 \\
\hline & $\mathrm{N}_{90} \mathrm{P}_{45} \mathrm{~K}_{45}$ & $55.3 \pm 0.3$ & 2.749 & 5.0 & $1020.3 \pm 2.5$ & 1.87 \\
\hline \multirow{5}{*}{ Binom } & $\begin{array}{c}\text { Without } \\
\text { fertilizers }\end{array}$ & $47.2 \pm 0.6$ & 1.965 & 4.5 & $618.7 \pm 2.2$ & 1.73 \\
\hline & $\mathrm{P}_{45} \mathrm{~K}_{45}$ & $47.4 \pm 0.6$ & 2.027 & 4.6 & $620.2 \pm 2.1$ & 1.76 \\
\hline & $\mathrm{N}_{45} \mathrm{P}_{45} \mathrm{~K}_{45}$ & $50.9 \pm 0.4$ & 2.330 & 5.3 & $925.1 \pm 3.2$ & 1.80 \\
\hline & $\mathrm{N}_{60} \mathrm{P}_{45} \mathrm{~K}_{45}$ & $53.1 \pm 0.9$ & 2.586 & 5.6 & $9972 \pm 1.9$ & 1.89 \\
\hline & $\mathrm{N}_{90} \mathrm{P}_{45} \mathrm{~K}_{45}$ & $54.4 \pm 0.6$ & 2.822 & 5.4 & $1035.8 \pm 3.8$ & 2.02 \\
\hline \multirow{5}{*}{ Terpal } & $\begin{array}{c}\text { Without } \\
\text { fertilizers }\end{array}$ & $46.0 \pm 0.6$ & 1.960 & 4.7 & $628.5 \pm 5.0$ & 1.83 \\
\hline & $\mathrm{P}_{45} \mathrm{~K}_{45}$ & $46.1 \pm 0.5$ & 2.015 & 4.7 & $630.2 \pm 4.1$ & 1.93 \\
\hline & $\mathrm{N}_{45} \mathrm{P}_{45} \mathrm{~K}_{45}$ & $49.7 \pm 0.4$ & 2.324 & 5.4 & $934.7 \pm 3.6$ & 2.04 \\
\hline & $\mathrm{N}_{60} \mathrm{P}_{45} \mathrm{~K}_{45}$ & $51.7 \pm 0.9$ & 2,534 & 5.9 & $1005.4 \pm 2.9$ & 2.22 \\
\hline & $\mathrm{N}_{90} \mathrm{P}_{45} \mathrm{~K}_{45}$ & $53.2 \pm 0.5$ & 2.784 & 5.8 & $1045.9 \pm 4.3$ & 2.29 \\
\hline
\end{tabular}

Note: ${ }^{*} \mathrm{M} \pm \mathrm{m}-\mathrm{a}$ confidence interval of the arithmetic mean at $5 \%$ level of significance.

Photosynthetic potential of the crop (FP) and leaf surface area of plants are closely interconnected. The conducted studies established that maximum indices of photosynthetic potential in Nabat variety (2.784-2.822 million $\mathrm{m}^{2}$.days/ha) was observed in the phase of milk-wax maturity in the experimental variants, where nitrogen fertilizers were applied at the rate of $\mathrm{N}_{90}$ on the phosphorus-and-potassium background and crops were sprayed with plant growth regulator Binom or Terpal at the beginning of the phase of tube formation, which was more than 1.220-1.143 million $\mathrm{m}^{2}$.days/ha compared to the minimum value of this indicator in the experiment (1.946 million $\mathrm{m}^{2}$.days/ha) observed in the control, where no treatment was applied.

According to the correlation-regression analysis, a close correlation was observed between the application of nitrogen fertilizers and the index of photosynthetic potential. Thus, the correlation coefficient was $r$ $=0,997$ in Nabat variety and $r=0,998$ in Vinnytskyi 28 variety. Application of morphoregulators Binom and Terpal also positively influenced the correlation coefficients, which was $r=0.916-0.967$ in Nabat variety and $r=$ 0.838-0.999 in Vinnytskyi 28 variety.

The dependence of photosynthetic potential on the combination of organized factors was revealed. The observed dependence can be described by the following regression equations: $y=98.648 \mathrm{~h}-186.3$ for the Nabat variety and $\mathrm{y}=107.27 \mathrm{~h}-184.16$ for Vinnytskyi 28 variety, where $\mathrm{y}$ - photosynthetic potential, million $\mathrm{m}^{2}$.days/ha; $x$ - rate of nitrogen fertilizers. Therefore, coefficient of multiple correlation is $R=0.990-0.992$; multiple determination coefficient is $\mathrm{R}^{2}=0.981-0.984$.

Effective activity of the leaf apparatus is determined by the net photosynthesis productivity (NPP). It has been already established that in the leguminous crops, the NPP formation is sinusoidal. When analyzing the dynamics of the net photosynthesis productivity of spring barley during 2009-2011, we have found out that they have a reverse dependence, in particular, these indicators increase from the stage of shoots to tube formation and reach their absolute maxima (5.3-5.8 $\mathrm{g} / \mathrm{m}^{2}$ per day), and then they gradually decrease till the phase of milkwax maturity $\left(2.1-2.0 \mathrm{~g} / \mathrm{m}^{2}\right.$ per day).

The established dependence can be explained by the fact that starting from the phase of full shoots to the beginning of tube formation there takes place an intensive growth of plant biomass, as the bulk of vegetative 
organs is being formed, besides the leaf surface area is still insignificant and there is practically no mutual shading of plants, therefore, the intensity of photosynthesis in the leaves of the lower and upper tiers is almost identical. A similar dependence was established in the studies by the Institute of Breeding and Genetic of NAAS [14].

The highest NPP dynamics was observed in the period of tillering in Nabat variety $\left(5.9-5.6 \mathrm{~g} / \mathrm{m}^{2}\right.$ per day), which exceeded the control by $1.8-1.5 \mathrm{~g} / \mathrm{m}^{2}$ per day, in the variant, where nitrogen fertilizers were applied at the rate of $\mathrm{N}_{60}$ on the phosphorus-and-potassium background and where Terpal or Binom were applied. This index was somewhat lower in Vinnytskyi variety $28\left(5.5-5.4 \mathrm{~g} / \mathrm{m}^{2}\right.$ per day), which was more than $1.6-1.5 \mathrm{~g} / \mathrm{m}^{2}$ per day than in the control, respectively.

On the basis of the dispersion analysis, it was found that application of nitrogen fertilizers provided favorable conditions at the initial stages of organogenesis and contributed to the intensive growth of biomass, and subsequently had an impact (15.59\%) on the synthesis of organic matter by spring barley crops and the increase in the index of NPP. The share of impact of application of morphoregulators was only $12.77 \%$. The impact of the variety and hydrothermal conditions on the NPP index was 3.4 and $48.63 \%$, respectively.

Along with this, it was established that application of nitrogen fertilizers at the rate of $\mathrm{N}_{45-90}$ and crop treatment with morphoregulators Binom or Terpal positively influenced the formation of the index of organic matter accumulation. The maximum indices were observed in the phase of milk-wax maturity and were 907.6$1045.9 \mathrm{~g} / \mathrm{m}^{2}$ in Nabat variety and $894.2-1035.1 \mathrm{~g} / \mathrm{m}^{2}$ in Vinnytskyi 28 variety, respectively. In this variant of the experiment, the maximum values of chlorophyll concentration " $a+b$ " in the leaves of spring barley were identified. The total chlorophyll index "a $+b$ " was $2.22 \mathrm{mg} / \mathrm{g}$ of crude mass $\mathrm{n}$ Nabat variety and $28-2.14 \mathrm{mg} / \mathrm{g}$ of crude mass in Vinnytskyi 28 variety.

As a result of the correlation-regression analysis, a strong positive correlation was established between organic matter accumulation and the rate of nitrogen fertilizers. Hence, it was $r=0,995$ in Nabat variety and $r=$ 0,881 in Vinnytskyi 28 variety.

High efficiency of the complex application of nitrogen fertilizers and crop treatment with morphoregulators in the phase of tube formation is proved both by the increased index of photosynthetic productivity and the level of grain yield of different crop varieties. The conducted studies show that the variants having the maximum indices of photosynthetic productivity had the maximum grain yield of spring barley. Thus, the maximum grain yield of 6.39 t/ha was observed in Nabat variety, and it was somewhat lower in Vinnytskyi 28 variety (5.78 t/ha), which was obtained under application of complete mineral fertilizer at the rate of $\mathrm{N}_{90} \mathrm{P}_{45} \mathrm{~K}_{45}$ and treatment with morphoregulator Terpal, which was more than 2.21 and $1.97 \mathrm{t} /$ ha than in the control (without treatment) (Table 2).

2. Grain yield of spring barley varieties depending on the rates of nitrogen fertilizers and treatment with plant growth regulators, $t / h a$ (on average for 2009-2011)

\begin{tabular}{|c|c|c|c|}
\hline \multirow{2}{*}{$\begin{array}{l}\text { Plant growth regulators (factor } \\
\mathrm{B} \text { - plant growth regulators) }\end{array}$} & \multirow{2}{*}{$\begin{array}{c}\text { Rates of mineral fertilizers } \\
\text { (factor } \mathrm{C} \text { - rates of mineral } \\
\text { fertilizers) }\end{array}$} & \multicolumn{2}{|c|}{ Varieties (factor A - variety) } \\
\hline & & Vinnytskyi 28 & Nabat \\
\hline \multirow{5}{*}{ Without PGR } & Without fertilizers & 3.81 & 4.18 \\
\hline & $\mathrm{P}_{45} \mathrm{~K}_{45}$ & 3.95 & 4.35 \\
\hline & $\mathrm{N}_{45} \mathrm{P}_{45} \mathrm{~K}_{45}$ & 4.97 & 5.08 \\
\hline & $\mathrm{N}_{60} \mathrm{P}_{45} \mathrm{~K}_{45}$ & 5.11 & 5.44 \\
\hline & $\mathrm{N}_{90} \mathrm{P}_{45} \mathrm{~K}_{45}$ & 5.38 & 5.66 \\
\hline \multirow{5}{*}{ Binom } & Without fertilizers & 4.10 & 4.38 \\
\hline & $\mathrm{P}_{45} \mathrm{~K}_{45}$ & 4.26 & 4.70 \\
\hline & $\mathrm{N}_{45} \mathrm{P}_{45} \mathrm{~K}_{45}$ & 5.21 & 5.46 \\
\hline & $\mathrm{N}_{60} \mathrm{P}_{45} \mathrm{~K}_{45}$ & 5.40 & 5.80 \\
\hline & $\mathrm{N}_{90} \mathrm{P}_{45} \mathrm{~K}_{45}$ & 5.68 & 6.05 \\
\hline \multirow{5}{*}{ Terpal } & Without fertilizers & 4.23 & 4.54 \\
\hline & $\mathrm{P}_{45} \mathrm{~K}_{45}$ & 4.38 & 4.78 \\
\hline & $\mathrm{N}_{45} \mathrm{P}_{45} \mathrm{~K}_{45}$ & 5.33 & 5.55 \\
\hline & $\mathrm{N}_{60} \mathrm{P}_{45} \mathrm{~K}_{45}$ & 5.54 & 6.01 \\
\hline & $\mathrm{N}_{90} \mathrm{P}_{45} \mathrm{~K}_{45}$ & 5.78 & 6.39 \\
\hline
\end{tabular}

Note: LPD $_{0.05}$ t/ha (on average for 2009-2011) A-0.105; B-0.129; C-0.166; AB-0.182; AC-0.235; BC-0.288; ABC-0.407 
It was established that higher rates of nitrogen fertilizers on the phosphorus-and-potassium background resulted in the increase in barley grain yield, in particular, by 0.9-1.6 t/ha when $\mathrm{N}_{45} \mathrm{P}_{45} \mathrm{~K}_{4}$ was applied, $1.26-1.3$ $\mathrm{t} / \mathrm{ha}-\mathrm{N}_{60} \mathrm{P}_{45} \mathrm{~K}_{45}$, and $1.48-1.57 \mathrm{t} / \mathrm{ha}-\mathrm{N}_{90} \mathrm{P}_{45} \mathrm{~K}_{45}$.

In addition, the increase in grain yield was influenced by the application of plant growth regulators. On the background of the increased nutrition with nitrogen, Terpal had a better effect on the crop yield and it ranged within $0.36-2.21$ t/ha or $8.61-52.87 \%$ in Nabat variety, while it was $0.42-1,97 \mathrm{t} / \mathrm{ha}$ or $11.02-51.71 \%$ in Vinnitskyi 28 variety; however, when applying Binom, the indices were somewhat lower, in particular, $0.20-1.87 \mathrm{t} / \mathrm{ha}$ or $4.78-44.74 \%$ and $0.29-1.87 \mathrm{t} /$ ha or $7.61-49.08 \%$ respectively.

\section{Conclusions}

Therefore, optimization of mineral nutrition due to the application of nitrogen fertilizers at the rate of $\mathrm{N}_{45-90}$ and treatment with growth regulator Terpal increased the intensity of the process of photosynthesis and the use of photosynthetic active radiation. Thus, maximum indices of photosynthetic productivity were formed in different phases and periods of growth and development of spring barley. The maximum leaf surface area was formed in the phase of earing and amounted to 46.0-55.3 thousand $\mathrm{m}^{2} / \mathrm{ha}$ in Nabat variety and 45.3-53.9 thousand $\mathrm{m}^{2} / \mathrm{ha}$ in Vinnytskyi 28 variety; the maximum index of net photosynthesis productivity (in the period of tillering-tube formation) and photosynthetic potential (in the phase of milk-wax maturity) were $4.1-5.9 \mathrm{~g} / \mathrm{m}^{2}$ per day in Nabat variety and 1.946-2.822 million $\mathrm{m}^{2}$.days/ha, and $3.9-5.5 \mathrm{~g} / \mathrm{m}^{2}$ per day and $1.804-2.542$ million $\mathrm{m}^{2}$.days/ha in Vinnytskyi 28 variety; the index of organic matter in the phase of milk-wax maturity was 603.1-1045.9 and $594.1-1035.1 \mathrm{~g} / \mathrm{m}^{2}$.

Therefore, optimization of the technology of spring barley cultivation due to the balanced system of fertilization, namely, application of nitrogen fertilizers at the rate of $\mathrm{N}_{90} \mathrm{P}_{45} \mathrm{~K}_{45}$ and treatment with plant growth regulators (Binom or Terpal) ensures the fulfilment of the genetic potential of such varieties as Nabat and Vinnitskyi 28 by $60-70 \%$ and grain yield by $6.39-5.78$ t/ha.

\section{References}

1. Beldii N., Zahynailo M., Nosulia A. (2012). Yachmin-kultura prybutkova [Barley as a profitable crop]. Proposytsiia [Proposition]. pp. 12-14. [in Ukraine].

2. Bomaba M.Y., Bomma M.I. (2001). Formirovanie urozhaiya yaroho yachmenia na Ukraine [Formation of spring barley in Ukraine]. Zernovye kultury [Grain Crops]. No2. pp. 22-24. [in Ukraine].

3. Yeremeiev V.N., Efimov V.V. (2003). Rehionalni aspekty hlobalnoi zminy klimatu. [Regional aspects of global climate change]. Visnyk NAN Ukrainy [Bulletin of the National Academy of Sciences of Ukraine]. No. 2. pp. 14-19. [in Ukraine].

4. Petrychenko V. F. (2012). Naukovi osnovy vyrobnytstva ta vykorystannia soi u tvarynnytstvi. Kormy i kormovyrobnytstvo [Scientific basis of soybean production and use in livestock breeding]. Kormy ta kormovyrobnytsvo [Feeds and Feed Production]. Issue. 71. pp. 108. [in Ukraine].

5. North J.J., Laubscher C.P., Ndakidemi P.A. (2010). Effect of the growth retardant Cycocel 8 in controlling the growth of Dombeya burgessiae. Afr. J. Biotechnol. No. 9 (29): pp.4529-4533. [in English].

6. Dospekhov B.A. (1985). Metodika polevogo opyta [Methodology of field experiment]. Moscow: Agropromizdat, 351 pp. [in Russian].

7. Nychyporovych A. A. (1956). Fotosintez i teoriya polucheniya vyisokih urozhaev. [Photosynthesis and the theory of obtaining high yields]. Timiryazevskoe chtenie [Timiryazevs reading]. Moscow, $94 \mathrm{pp}$. [in Russian].

8. Gold V.M., Gaevskiy N.A., Golovanova T.I. (2008). Fiziologiya rasteniy: metod. ukazaniya po lab. Rabotam [Plant physiology: methodological instructions on the laboratory work]. Krasnoyarsk: IPK SFU. 61 pp. [in Russian].

9. Murchie E.H., Niyogi K.K. (2011). Manipulation of photoprotection to improve plant photosynthesis. Plant Physiol. (155). 1. pp. 86-92. [in English]. 
10. Dodd I.C., Whalley W.R., Ober E.S. et al. (2011). Genetic and management approaches to boost UK wheat yields by ameliorating water deficits. J. Exp. Bot. 62. pp. 5241-5248. [in English].

11. Petrychenko V.F. (2003). Naukovi osnovy suchasnykh tekhnolohii vyroshchuvannia vysokobilkovykh kultur [Scientific fundamentals of modern technologies for the cultivation of high protein crops]. Visnyk ahrarnoi nauky [Bulletin of Agrarian Science]. Kyiv. pp. 15-19. [in Ukraine].

12. Kalenskaia S.M., Tokar B.Y. (2015). Urozhaynost yachmenya yarovogo v zavisimosti ot urovnya mineralnogo pitaniya [Productivity of spring barley depending on the level of mineral nutrition]. Naukovi pratsi Institutu Bioenerhetychnykh kultur i tsukrovykh buriakiv. [Scientific works of the Institute of Bioenergy Crops and Sugar Beet]. Issue. 23. pp. 30-33. [in Ukraine].

13. Deieva V.P. (1980). Retardanty-regulyatory rosta rasteniy [Retardants as plant growth regulators]. Minsk: Science and Technology, 176 pp. [in Bielarus].

14. Rybalko O.I., Morhun B.V., Polishchuk S.C. (2016). Yachmin yak produkt funktsionalnoho kharchuvannia [Barley as a product of functional nutrition]. Kyiv: Lohos. 619 pp. [in Ukraine]. 